\title{
Role of Board of Governors and Parent Teacher Associations in District Public Schools in the Context of Conflicts and Challenges
}

\author{
Ijaz Ahmad Tatlah", Muhammad Zafar Iqbal \\ Department of Education, University of Management and Technology, Lahore, 54600, Pakistan
}

\begin{abstract}
Sharing governance in schools to facilitate and support the schools at grass root level yielded Board of Governors (BOGs) and parent teacher association (PTAs). At present it has become a recognized phenomenon. In one or the other way parents constitute part of the school governance structure. Their involvement and active support in teaching and learning is critical to sustained educational quality. The main focus of the study is on conflicts and challenges associated with the role of Board of Governors (BOG) and Parent Teacher Association (PTA).This study is survey design comprising of heads (30), chairs of BOGs (30) and PTAs (30), and was conducted in the thirty Districts of Punjab, Pakistan to investigate the role of BOGs and PTA in the teaching and learning process. A questionnaire was served on heads and chairs of BOG and PTA in thirty purposively sampled mixed schools. The questionnaire format consisted of closed, open-ended and rating scale items. While BOGs and PTAs were considered part of the school leadership team, they perceived their roles differently and operated in an environment characterized by contradictions, challenges, tensions and conflicts, which were attributed to role overlap and lack of clear guidelines resulting in roles overlap. The study also identifies lack of training and, appropriate induction programme and induction pack as challenges that impede the roles of the BOGs and PTAs. Also a majority of the BOGs and PTAs lacked confidence in their roles.
\end{abstract}

Keywords Parents-Teachers Association (PTA), Board of Governors (BOG), Perceptions, Role Conflicts, District Public Schools

\section{Introduction}

Parental involvement in schools through BOG and PTA has been widely acknowledged in both developing and developed countries (Brain and Reid, 2003 \& Kamba, 2010a). The parental involvement is associated with school effectiveness and children performance in general. This view is also held by Clase (2007) Parental involvement despite the educational background or social position of the parents is an essential component for successful education and teaching at school level. Commenting in favour of parental involvement in schools, Massey (1993) views that;

"It is a mistake to underestimate the willingness and capacity of many parents to work with the school, and an even bigger mistake to cling to old ways which although cozy and comfortable do not meet present or future needs".

According to Allemano (2003) the notion of parental involvement is active support from key stakeholders, and is critical to sustained educational quality. James (2010a)

* Corresponding author:

tatlah333@yahoo.com (Ijaz Ahmad Tatlah)

Published online at http://journal.sapub.org/mm

Copyright $(2011$ Scientific \& Academic Publishing. All Rights Reserved observed that school governors comprise the school governance networks. Lin (2010a) reported that parental support is a critical factor in the success of the school and that cooperation between teachers and parents enhances the pupils' performance. Kamba (2010b) also observed that involving stakeholders in governance and management of schools improves the quality of education system. Parental involvement in schools takes different kinds and forms or aspects. However, this article focuses only on Board of Governors (BOG) and Parent Teacher Association (PTA). BOG and PTA constitute part of the formal structures of governance through which parents and the community are enabled to participate in the education of their children. It is assumed that through such structures educational provision is enhanced, and school governance and educational quality is improved.

According to Azeem (2010) school governance generally becomes weak due to poor parental involvement in school financial management and key decision making areas.

The Scottish Parents Teachers Council (SPTC) offers the following definition of PTA which is very fitting in the parental involvement discourse (Edwards and Redfern, 1988a):

"A local people who recognize that the education of a child is a process of partnership between parents and 
teachers and who wish to take joint action to improve the quality of that partnership".

BOG and PTA both contribute to educational development in various ways and because of their nature and status are meant to perform different but complementary roles in the school. James (2010b) argued that school governors give an enormous amount to the education system in England, yet their contribution is largely hidden from public view. However, in a number of cases evidence suggests that their roles occasionally overlap resulting in tensions and conflicts (World Bank, 2008a). In many education systems in developing countries there are tensions and conflicts in the roles of PTAs and SMCs (Dunne, 2007). According to Ramani and Zhimin (2010) role conflict involves real differences in role definitions, expectations or responsibilities between individuals who are interdependent in social systems. If there are ambiguities in role definitions in an organization or unclear boundaries of responsibilities, then the stage is set for interpersonal frictions between the stakeholders.

\section{Board of Governors (BOG)}

As mentioned earlier although BOGs are voluntary in nature they have a legal mandate. In both developed and developing countries and especially within the last thirty years there has been a growing move through legislation to involve parents in the education of their children through school governing bodies. The move resulted in the transfer of powers and responsibilities from local authorities to individual schools. Therefore, through legislative reforms, school governors received a legal backing. Decision-making was devolved to school governing bodies (Field, 1993).Through legislative reforms the governors received statutory responsibilities (Wilson, 2001) and became part of the schools' leadership (Earley, 2003).

\section{Parent-Teacher Association (PTA)}

The historical development of PTA in both the developed and developing countries is partly linked to school board of governors' failures and partly due to the need for extra financial support from the local community for school development (Hurt, 1985). In Pakistan PTA/SMC School Management Committees were created in the light of National Educational Policy 1998. It is assumed that it was set up to raise extra funds for school development, however, later on there seems to be a growing feeling that BOGs are politically elected and therefore are not the right forum to address the interest and needs of parents and the community in general (World Bank, 2008b).Therefore PTAs are seen as a better option. Macbeth (1990) has identified six purposes of a parental association but warns that they may conflict in their roles such as to provide support for teachers; to represent parent's interest; to provide a forum for educational discussion and a means of communication; to foster educational partnership between home and school for the benefit of children; to assist members who have difficulties; to advance an ideology (e.g. religious, educational etc).

In the UK the current breed of PTAs is strongly associated with the Plowden report, which recognized it as an important means by which parents could be involved in the life of the school (Edwards and Redfern, 1988b). In the USA, Lin (2010b) reported a number of roles performed by PTAs, they include, involving parents in classroom decision, promoting communications, social events and fundraising and, lobbying the state and national legislatives on behalf of the students. The PTAs forum therefore affords parents and teachers an opportunity to socialize and raise funds (Yahie, 2000).

In Punjab Province, Pakistan in public schools, management committees (SMCs and Parent Teachers Association (PTAs) are responsible for the management and provision of learning and teaching materials. Besides undertaking management roles, they also play a significant role in monitoring funds. Their umbrella body is Education District Officer, which was introduced in 2001. Their aim is to enhance participation of parents in the leadership and management of public educational affairs. However, literature is limited on PTAs involvement in secondary schools in Pakistan. But, this is almost certain that the governing bodies of schools in Punjab District Governments are worried about concerns of people.

\section{Methodology}

The main focus of the study is on school governing bodies' roles, issues and challenges. Thirty District public schools were purposively sampled for study. In order to understand the roles, issues and challenges faced by the school governing bodies, a variety of data were required. This includes questionnaires and informal interview data from the school heads and chairs of school governing bodies (BOG) and parent- teachers association (PTA) on their roles in school management, their involvement in the teaching and learning process and the challenges they faced. Questionnaires were served and the response rate was $100 \%$. The questionnaire questions format consisted of closed, open-ended and rating scale items. This was necessary to diversify responses as well as reduce what Watson and Coombes (2009) call 'question fatigue'.

\section{Results}

The participants comprised of chairs of Board of governors (BOG), chairs of parents teachers association (PTA) and head teachers, and data were analysed categorically .All the chairs of Board of governors who took part in the study were male. Ninety percent $(90 \%, \mathrm{n}=30)$ of them had beyond primary education and less than half (slightly over $40 \%$ ) were either professional or semi-professionals. About the level of education an open-ended section was provided in the questionnaire, where they were asked to specify and their responses included, primary, and middle, Diploma, college and university. Also, about occupation an open-ended section was provided for them to specify, and they identified their occupations as, retired police officer, Govt.officer, retired army person, airline industry and peasant. Assuming 
that the BOG was mainly lay people on educational matters. All numbers are rounded to the nearest $10 \%$. The results show that BOG and PTA membership in secondary schools is drawn from people of diverse occupational skills and people of different levels in educational achievement. Nearly all heads $(90 \%, n=30)$ who took part in the study were male while only $10 \%(n=30)$ were female. All participants $(100 \%$, $\mathrm{n}=30$ ) had beyond primary education. When asked to specify, their responses included, diploma in education, university degree and Masters Degree in education (M.Ed.).About experience in headship, half of the respondents $(50 \%)$ had less than 5 years of experience, while slightly less than half $(40 \%, \mathrm{n}=30)$ had more than 5 years. Just a small portion $(10 \%)$ had over 10 years. More than three quarters $(80 \%)$ of the participants had served in the current school for 2 years and more. It is emerges that majority of heads in secondary schools are inexperienced and have only been in their current stations for a short period of time. Ninety percent $(90 \%$, $\mathrm{n}=30$ ) of the parents teachers association (PTA) participants were male, while $10 \%(n=30)$ were female. Fewer than $90 \%$ had beyond primary education level. Half were either professional or semi-professional. Their profession included religion scholar/Pesh Imam, politician (councillor), farmer, nurse aid and businessmen. It was found that PTAs were mainly lay people in the field of education.

\section{Differential perceptions of BOG and PTA roles}

The BOG and PTA respondents were asked to identify by ticking on the given box what they thought was their role or responsibility. But the head teachers were asked to identify by ticking on the given table whose task they thought it was, BOG, PTA or both. Their task was to identify from a set of roles provided and were asked to say what they thought described their roles. Their responses were tabulated as shown in table 1 below.

Table 1 shows differences in perceptions between the head teachers, BOG and PTA about various roles in secondary schools. In their responses, PTA scored highly (over $80 \%$ ) on the following areas or roles.

Identification of school development projects $=80 \%$, Looking after the welfare of the school community $=80 \%$, Improvement of school performance $=80 \%$, Raising funds for various school projects $=90 \%$, School finance management $=90 \%$

This may put forward a positive perception about these roles. Further, suggesting that they felt that it was their responsibility to support their schools in those areas. PTA scored medium (60-79\%) on the following 3 areas.

Quality standard assurance $=60 \%$, Maintenance of discipline in the schools $=70 \%$, Maintenance of school environment $=70 \%$, But scored poorly $(40 \%)$ on the following other 3 areas like curriculum implementation $=30 \%$, Salary review $=40 \%$, Recruitment of staff $=40 \%$, majority of the PTAs did not consider them their major roles.

BOG scored highly (80-90\%) on the following four areas; School finance management $=90 \%$, Improvement of school performance $=80 \%$, Recruitment of staff $=90 \%$, Identifica- tion of development project $=90 \%$.

BOG scored medium (60-79\%) on the following six areaș:Maintenance of discipline in the school $=89 \%$, Looking after the welfare of the school community $=70 \%$, Salary review $=70 \%$, Raising funds for various school projects $=$ $60 \%$. Maintenance of the school environment $=60 \%$, Quality standard assurance $=70 \%$, BOG scored poorly $(50 \%)$ on the curriculum implementation $=50 \%$.Suggesting that curriculum implementation was considered as the least role played by both BOG and PTA in secondary schools in Punjab, Pakistan.

Table1 also reveals some tensions between BOG and PTA in relation to roles such as $90 \%(n=30)$ of $B O G$ viewed school finance management to be their role, while $90 \%$ $(n=30)$ of PTA views it as their role as well. But $80 \%(n=30)$ of head teachers saw it as a BOG job and not that of PTA. This may help explain the reasons for conflicts between Bogs and PTAs on their roles in management of finances in schools.

Table 1. Differential Perceptions of Various Roles

\begin{tabular}{|c|c|c|c|c|c|}
\hline Roles & $\begin{array}{l}\mathrm{Hea} \\
\mathrm{BOG}\end{array}$ & (\%) & $\begin{array}{l}\mathrm{n}=30 \\
\mathrm{OTH}\end{array}$ & BOG $(\%) n=30$ & $\begin{array}{c}\mathrm{PTA}(\%) \\
\mathrm{n}=30\end{array}$ \\
\hline $\begin{array}{c}\text { Identify school } \\
\text { development pro- } \\
\text { ject }\end{array}$ & 10 & 30 & 60 & 90 & 80 \\
\hline $\begin{array}{l}\text { Curriculum imple- } \\
\text { mentation }\end{array}$ & 30 & 10 & 50 & 50 & 30 \\
\hline Salary review & 90 & 0 & 10 & 70 & 40 \\
\hline Recruitment of staff & 90 & 0 & 10 & 90 & 40 \\
\hline $\begin{array}{l}\text { Look after the } \\
\text { welfare of the } \\
\text { school community }\end{array}$ & 10 & 20 & 60 & 70 & 80 \\
\hline $\begin{array}{l}\text { Quality standard } \\
\text { assurance }\end{array}$ & 20 & 0 & 80 & 70 & 60 \\
\hline $\begin{array}{l}\text { Improvement of } \\
\text { school performance }\end{array}$ & 10 & 0 & 90 & 80 & 80 \\
\hline $\begin{array}{l}\text { Maintenance of } \\
\text { discipline in the } \\
\text { school }\end{array}$ & 50 & 0 & 50 & 89 & 70 \\
\hline $\begin{array}{l}\text { Maintaining school } \\
\text { environment }\end{array}$ & 10 & 30 & 60 & 70 & 70 \\
\hline $\begin{array}{l}\text { Raising funds for } \\
\text { various school } \\
\text { projects }\end{array}$ & 20 & 50 & 30 & 60 & 90 \\
\hline $\begin{array}{l}\text { School finance } \\
\text { management }\end{array}$ & 80 & 0 & 20 & 90 & 90 \\
\hline
\end{tabular}

\section{Over all perceptions about the roles of BOGs and PTAs in order of importance}

Both BOGs and PTAs were asked to show as individuals their roles in the order of importance and their responses were recorded as shown in table 2 below.

The two groups i.e. BOG and PTA scored low in curriculum implementation, suggesting that a significant number of them did not consider it their responsibility.

\section{Issues, Challenges and Conflicts}

One of the issues identified relates to lack of training. BOG participants were asked if they received any training that prepared/equipped them for various roles in the teaching-learning process. Just under half of the BOGs who took 
part in the study indicated they received training which they found very useful. Asked to specify on the training they received on the open-ended section. Such as the training comprised seminars and workshops on various aspects of their roles, for instance, school management, improvement of education standards, roles of BOG, financial management, education administration and coordination of school activities. Also seminars with District Education Officers (DEO). There is also the initial meeting where BOG meets with professionals from the Ministry of Education and EDO office. During the meeting all BOG members receive appointment letters and a seminar on their roles. Thereafter, the principal continues with their learning and development. The issue of lack of training was also identified in the study by head teachers. Forty percent $(40 \%, n=30)$ indicated that BOG did receive training in relation to their roles. Fifty percent $(50 \%, n=30)$ of the head teachers indicated that BOG training will serve a purpose and just under $80 \%$ admitted that such training was necessary.

Table 2. BOG and PTAs' roles in order of importance and on the basis of individual perceptions

\begin{tabular}{|c|c|}
\hline BOG Roles in order of importance & PTA Roles in order of importance \\
\hline School finance management $(90 \%)$ & School finance management $(90 \%)$ \\
\hline Identify school develop. project $(90 \%)$ & Raising funds for projects $(90 \%)$ \\
\hline Recruitment of staff $(90 \%)$ & Identify school develop proj. $(80 \%)$ \\
\hline Improvement of school perf. $(80 \%)$ & Look after school welfare $(80 \%)$ \\
\hline Maintenance of discipline $(80 \%)$ & Improvement of school perf. $(80 \%)$ \\
\hline Salary review (70\%) & Maintaining school environ (70\%) \\
\hline Look after the school welfare (70\%) & Quality of discipline in school (70\%) \\
\hline Maintaining of school environ $(70 \%)$ & Quality standard assurance $(60 \%)$ \\
\hline Quality standard assurance $(70 \%)$ & Salary review $(40 \%)$ \\
\hline Raising funds for school proj. $(60 \%)$ & Recruitment of staff $(40 \%)$ \\
\hline Curriculum implementation $(50 \%)$ & Curriculum implementation $(30 \%)$ \\
\hline
\end{tabular}

The other issue considered is that of training and induction pack. Slightly over half $(60 \%, n=30)$ of the BOG said that they received some sort of induction into their roles. Their comments on the open-ended section where they were asked to specify on the sort of induction they received reveal the following:

1. Seminars where issues such as school management, learning and improving standards are covered. Also specific roles that need to be carried out in the school are covered.

2. Usually done to new school governors during BOG meetings and briefings.

3. Through briefings by the principal of the school.

4. Also through periodical meetings with the principal.

On the induction pack, just fewer than $40 \%(n=30)$ indicated that there was induction pack for new BOG that introduced them into their roles and the teaching-learning environment. For those who responded 'no' to the question on induction pack they were asked to identify ways by which they came to understand their roles.

Something that is positive and encouraging on the one hand, but on the other hand raised questions how they gained such confidence. But one head teacher commented that most of the BOG and PTA complete their term without knowing and/or understanding their roles. The study also indicates that BOG experience a number of challenges as they dis-

charge their roles. They are illustrated in the table 3 below:

Table 3. Challenges that BOGs and PTAs Experience

$$
\text { Challenges }
$$

Lack of adequate funding

Lack of parental support

Unnecessary red tape

Lack of co-operation between PTA and BOG

Lack of co-operation between parents and principal

Lack of recognition in the Education Act

Lack of co-operation between PTA and principal

Lack of support from the principal

Lack of support among BOG

$\begin{array}{cc}\text { PTAs } & \text { BOG } \\ (\%, \mathrm{n}=30) & (\%, \mathrm{n}=30) \\ 90 & 100 \\ 70 & 60 \\ 30 & 50 \\ 40 & 40 \\ 20 & 40 \\ 50 & 40 \\ 10 & 30 \\ 20 & 30 \\ 30 & 20\end{array}$

For BOG out of the nine challenges identified in the study, the last seven may be of less effect compared to the first two. In other words they don't perceive them as significant challenges. For PTAs three challenges $(50 \%-90 \%)$ i.e. Lack of adequate funding, Lack of parental support and Lack of recognition in the Education Act may be significant and may require attention, while the rest $(10 \%-40 \%)$ may be less significant. The study also reveals that BOG operates in an environment full of conflicts and tensions as illustrated in table 4 below:

\section{Head-teachers perception of possible cause of conflicts between BOGs and PTAs}

Head teachers were asked to identify the possible causes of conflicts from the list provided as shown in table 4 below.

Table 4. Conflicts in relations to BOG roles: BOG

$\begin{array}{cc}\text { Sources of Conflicts } & \%, \mathrm{n}=30 \\ \text { Conflict of interest } & 70 \\ \text { Raising and spending of money on school projects } & 70 \\ \text { Non-recognition of PTA by the Education Act } & 60 \\ \text { Lack of clear operational guidelines } & 50 \\ \text { Lack of understanding of our roles as BOG } & 50 \\ \text { Poor working relationship with PTA } & 40 \\ \text { members I feel we are not in full control of the school finances } & 40 \\ \text { that out on major decision making processes on school development } & 40\end{array}$

The study identifies nine sources of conflicts that impact on BOG as they discharge their roles. The first five seems to be of major concern compared to the last four. Despite the sources of conflicts identified the following emerged from the study: Seventy percent (70\%) indicated that the resulting conflicts are resolved, for example through mediation committees or teams, improved communication and sponsor intervention for those schools that have sponsors. Ninety $(90 \%)$ regarded PTA as partners in the teaching-learning process. All $(100 \%)$ of the study participants indicated that they regarded BOG, PTA and head teachers as one team in the teaching-learning process. Eighty percent $(80 \%)$ felt that the relationship between PTA and BOG was good, very good and excellent. Ninety $(90 \%)$ felt that the relationship between BOG and head teacher was good, very good and excellent. Also $100 \%$ felt that the relationship had a positive impact on the teaching-learning process.

The head teachers also indicated that some conflicts emerge as PTA plays their roles.

These are contained in table 5 below: 
Table 5. Sources of Conflicts in Relation to PTAs roles: PTAs Perception

$$
\begin{array}{cc}
\text { Sources of conflict } & \%, \mathrm{n}=30 \\
\text { Lack of understanding of their roles } & 90 \\
\text { Lack of operational guidelines } & 60 \\
\text { PTA wants to have more control and power on } & 70 \\
\text { the raising and management of finances } & 60 \\
\text { Head teacher leaning towards BOG } & 30 \\
\text { Poor working relationship with BOG } & 50 \\
\text { A feeling of being left out in major decision } & 70 \\
\text { making in school development } & \text { Lack of understanding of roles } \\
\text { Raising and spending money on school de- } & 70 \\
\text { velopment projects } & \\
\text { Non-recognition of PTA by the Education } & 60 \\
\text { Policy }
\end{array}
$$

30

PTA's perception of sources of conflict between BOGs and PTAs

In the PTAs questionnaire, respondents were asked to identify the conflicts that emerge as PTAs play their role in school. A number of possible causes of the conflict were provided and respondents were required to give a 'yes' or 'no' answer. Their responses were provided as in table 5 .

A part from 'poor working relationship with BOG' the rest of the sources of conflicts were perceived as very significant.

\section{Discussion}

Parental involvement in education through BOGs and PTAs and their roles has been widely reported. However, fewer studies have been conducted in Pakistan, due to the fact that this area has not attracted many researchers' attention. The current study set out to investigate how BOGs and PTAs perceived their roles. The results showed that there were significant differential perceptions of roles between PTAs, BOGs and heads as has been described in table 1.

From table 2, heads perceptions about PTAs and BOGs role paints a different picture, resulting in two typologies i.e. separate or individual roles and shared or joint roles. Separate or individual roles refer to the roles that are perceived as either PTAs or BOGs. Shared roles refer to the roles that the head teachers have indicated both suggesting that the roles are for both BOGs and PTAs.

PTAs list is long and may suggest that they are really struggling to deliver their services to school. And one wonders for how long things will go on like this. Lack of guidelines was also mentioned in the review. The study also revealed that PTAs and BOG experiences challenges as they performed various roles.

\section{Conclusions}

Parental involvement in education through BOGs and PTAs are now widely recognized. The BOGs are considered part of the school leadership. BOGs and PTAs are considered part of the school governance structure. Their involvement is underpinned by the assumption that they would contribute positively to the learning of their children and therefore the quality of education would improve and that children would attain better results. Also that children's behaviour would improve. BOGs roles are driven by legislative reforms, while PTAs are purely voluntary. But questions have been raised in relations to their commitments, skills and capacity to perform certain roles. While PTAs have been recognized for raising extra funds for various development projects among other activities in the life of the school, concerns have been reported regarding fund-raising activities. Many of the parents resent fundraising events employed PTAs; as a result membership has been negatively affected.

Resentments have also been reported regarding BOG and PTA involvement in education in general because they are regarded as non-professional and lay people operation in a foreign territory, that of professionals.

\section{REFERENCES}

[1] Allemano, E (2003) HIV/AIDS: A threat to educational quality in Sub-Saharan Africa: An analytical framework and implications for policy development. Association for the Development of Education in Africa. www.ibe.unesco.org

[2] Azeem, V (2010) An overview of the African Education Watch Ghana report. www.tighana.org

[3] Brain and Reid (2003) Constructing parental involvement in an Education Action Zone: Whose need is it meeting? Educational Studies, 29(2/3) pp. 292-305

[4] Clase, P.; Kok, J. and Van der Merwe, M. (2007). Tension between school governing bodies and education authorities in South Africa and proposed resolutions. South Africa Journal of Education 27(2) 243-263

[5] Dunne, M; Akyeampong, K.; Humphreys, S. (2007). School processes, local governance and community participation to access: Research monograph N0 6

[6] Edwards, V and Red, F. (1988) At home in school: parent participation in primary school. London: Routledge.

[7] Earley, P. (2003) Leaders or followers: Governing bodies and their role in school leadership.Educational Management and Administration, 31(4), p.353-367

[8] Field, L. (1993) School governing bodies: the lay- professional relationship. School Organization,13(2), pp.165-174

[9] Hurt, J. (1985) Parental involvement in school: a historical perspective. In Cullingford C. (Ed.) Parents, teachers and schools. London: Robert Royce Ltd.pp. 17-39

[10] James, C.; Brammer, S.; Connolly, M; Fertig, M.; James. J.; Jones, J. (2010) the 'hidden givers' a study of school governing bodies in England. www.cfbt.com/evidenceforedu cation

[11] Kamba, K. (2010) Education development in Southern Sudan: A study of community participation and democratic leadership in two primary schools in Central Equatoria State, Southern Sudan. Oslo University College: Faculty of Education and International Studies 
[12] Lin, R. (2010) The role of parent-teacher associations. www.ehow.co.uk

[13] Macbeth, A. (1990) Involving parents: effective parent-teacher relations. London: Heinemann Educational

[14] Massey, R.(1993) Parent power: securing the best schooling for your child. Cambridge: Harmsworth Publishing Ltd

[15] Ramani, K. \& Zhimin, L. (2010) A survey on conflict resolution mechanisms in public secondary schools: A case of Nairobi Kenya

[16] Watson, M. and Coombes, L. (2009) Surveys. In Neale Joanne(ed.) Research methods for health and social care.Basingstoke: Palgrave 5. Macmillan pp.121-136
[17] Wilson, M. (2001) Comprehensive school governance and special needs provision: policy, practice and future priorities. Educational Management and Administration, 29(1), p.49-62

[18] World Bank (2008) Governance, management, and Accountability in secondary education in Sub-Saharan Africa. Washington: The world Bank

[19] World Bank (2008a) Transitions in secondary education in Sub-Saharan Africa: equity and efficiency issues. World Bank working paper No.125, Africa human development series

[20] Yahie, A. (2000) Poverty reduction in Sub-Saharan Africa: Is there a role for the private sector. African Development Bank: Economic Research Papers No.52 